\title{
Circular Economy - Challenges for Mining and Power Generation as Exemplified by Poland
}

\author{
Michał Kozioł \\ Silesian University of Technology, Poland \\ Joachim Kozioł \\ University of Zielona Gora, Poland
}

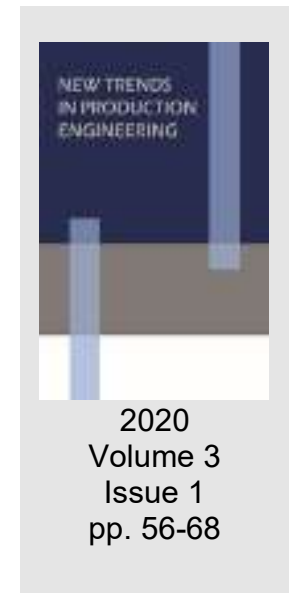

Date of submission to the Editor: 02/2020

Date of acceptance by the Editor: 03/2020

\section{INTRODUCTION}

Compared to concepts such as: "sustainable development", "green economy", "clean production", "low-carbon economy", "waste-free economy", which are already very widely used, the term circular economy is a new concept. Although, at the same time, more and more information can be found both in the mass media and in scientific publications concerning this new approach to environmental issues in the broadest sense of the term (e.g: Zhaoa et al, 2012; Makropoulos et al, 2018; Careddu, 2019).

With its assumptions, circular economy is the answer to current economic, environmental and social challenges. In relation to the concepts hidden under the terms mentioned at the beginning of the chapter, it is characterized by complexity and multidimensionality (economic, environmental, social, legal, educational and scientific dimensions). An important feature of circular economy is also the targeted impact on lifestyles and to a large extent on the world view and mentality of societies.

Particular importance is attached to circular economy in the European Union, where its implementation has been preceded by the preparation of planning documents and the implementation itself is based on numerous legal provisions. The lack of common and thorough knowledge among managerial staff regarding the economic processes that will force the implementation of circular economy in EU countries is a serious threat to the long-term functioning of a number of companies and even industries.

\section{OVERVIEW OF CIRCULAR ECONOMY}

There is still no clear or widely accepted definition of circular economy in the world (Zhaoa et al, 2012; Careddu, 2019). In Kirchherr, Reike \& Hekkert (2017) 114 definitions of this term were analysed. As shown in the publication cited, many definitions differ significantly from one another. There are also many 
problems with the relationship between circular economy and sustainable development.

One of the definitions that can be considered to be defining the concept of circular economy relatively well is given in the Roadmap for the Transformation to Circular Economy (Council of Ministers, 2019): "circular economy is a model of economic development in which the following basic assumptions are met, while at the same time maintaining the condition of productivity:

(a) the added value of the raw materials/resources, materials and products is maximized or

(b) the amount of waste generated is minimized and the resulting waste is managed in accordance with the hierarchy of waste management (waste prevention, preparation for re-use, recycling, other manner of recovery, disposal)'.

This definition can be considered as an extension of the definition of circular economy contained in (European Commission, 2015).

The above effects are to be obtained as a result of moving away from a linear economy, in which processes occur in the following order: extraction of raw material, production, use, waste disposal, towards a circular model in which processes occur in the following order: production, use, use of waste as a raw material in the following production cycle, use, etc. In the practice of economic life, the circular model of economy will also need to be fed with raw materials. However, the scale of such feeding is to be much smaller than in the linear economy model.

The transition from a linear to a circular economy model is often considered the definition of the concept of "circular economy" (Zhaoa et al, 2012; Favot \& Massarutto, 2019).

In the case of circular economy we distinguish between the biological cycle and technical cycle. The biological cycle refers to economic processes involving raw materials and biological products (mainly of agricultural and forestry origin). In this cycle, the waste is used, among other things, as fertilisers, so that the substances it contains are reused as e.g. agricultural products. Another use of waste is to produce biochemical raw materials or to produce biogas. The "technical" cycle is based on raw materials of mining origin. Within this cycle, products are recycled in such a manner that raw materials are reclaimed after a longer and more efficient use than it is being used currently. In the case of both cycles, waste with no other use (according to the hierarchy of the manner of proceeding with waste) is subject to energy recovery and substances with no other use are landfilled.

The important role played by consumers in the circular economy should be highlighted. It is only through their actions that longer and more efficient use of raw materials and products is possible. Consumers will be responsible for the maintenance and repair of products, the redistribution of products and the use of refurbished products. Consumers should also move from a model of ownership to a model of use, in addition the efficiency of use should 
be improved through product sharing. In addition, the desire to reduce food waste is largely based on the consumers' decisions.

Another important element of circular economy is eco-design. Its aim is to obtain products that are more durable, easier to repair and maintain, easier to dismantle, based on renewable raw materials to a larger extent and having lower energy consumption. Furthermore, they should be based on locally available raw materials and the production process must be characterized by minimizing environmental impact.

The expected effects of implementing circular economy are:

- reducing the consumption of resources, in particular non-renewable raw materials,

- reducing the environmental impact (e.g. reduction of pollutant emissions, reduction of the impact on the landscape),

limiting the increase in raw material and land prices,

reducing energy consumption,

increasing the number of jobs, in particular in the service sector,

research and technological development,

the increased independence of individual countries, economic areas and certain industries from raw material suppliers.

\section{CIRCULAR ECONOMY IN THE EUROPEAN UNION}

Work on formalizing circular economy processes in the EU dates back to the initial years of the second decade of the 21st century. In July 2014 the European Commission presented the first document outlining the vision of circular economy in the EU: "Towards a circular economy: A zero waste programme for Europe" (European Commission, 2014). The document estimated that improving resource management could reduce demand for raw materials in the EU by $17-24 \%$ by 2030 , and could bring savings in the European industry of $€ 600-630$ billion per year. The document also indicated the achievable reduction of greenhouse gas emissions of $2-4 \%$ per year.

Despite its seemingly ambitious assumptions, the project met with criticism, one of the reasons for which was the excessive focus on waste management. Therefore a new action plan was presented by the European Commission in December 2015 in a communication entitled: "Closing the loop - An EU action plan for the Circular Economy" (European Commission, 2015). In addition to minimizing waste generation, the new document paid more attention than before to areas such as wasting food, consumption, construction, critical raw materials, mining and industrial waste, plastics, public procurement, fertilisation and water use (including its reuse in agriculture and groundwater supply). The envisaged measures also include an improved energy efficiency labeling system for household appliances and other energy-related products. Priority areas include: food waste, plastics, critical raw materials, construction and demolition waste, biomass and bioproducts. The document discusses relatively broadly the following issues: recycling, secondary raw materials market as well as a new model of consumption (based, among others, on better enforcement 
of guarantees, durability of products and their repairs and sharing). In both documents discussed, particular attention was paid to the role of small and medium-sized enterprises in circular economy.

The implementation of the above-mentioned plan will require a rapid and costly adaptation effort in the case of a number of countries. The scale of the changes implemented can be seen in the examples provided below.

One of the elements of the implementation of the plan discussed above is the Directive of the European Parliament and of the Council of the EU (Directive EU 2018/851), which among others provides for increasing the minimum mass fraction of municipal waste prepared for re-use and recycling: 55\% in $2025,60 \%$ in 2030 and $65 \%$ in 2035. The Directive also provides for the possibility to postpone these deadlines by 5 years for countries which landfilled more than $60 \%$ of municipal waste in 2013 or where less than $20 \%$ of municipal waste was prepared for re-use and recycled.

In parallel, Directive EU 2018/850 was published, providing for EU countries to take the necessary measures to ensure that, by 2035 , the quantity of municipal waste landfilled is decreased to not more than $10 \%$ of its total generated weight. Again, for countries with more than $60 \%$ of municipal waste disposed of in 2013, the implementation of this regulation is foreseen 5 years later.

A significant part of municipal waste is packaging waste. Together with the directives discussed above (in the same Official Journal of the European Union), EU Directive 2018/852 has been published, providing for minimum recycling rates in 2025 and 2030 for packaging waste as shown in Table 1.

Table 1 Minimum recycling targets for packaging waste and individual materials contained in this waste

\begin{tabular}{|l|c|c|}
\hline \multirow{2}{*}{$\begin{array}{c}\text { Material contained in packaging } \\
\text { waste }\end{array}$} & \multicolumn{2}{|c|}{ Year } \\
\cline { 2 - 3 } & $\mathbf{2 0 2 5}$ & $\mathbf{2 0 3 0}$ \\
\cline { 2 - 3 } & \multicolumn{2}{|c|}{$\begin{array}{c}\text { \% of weight of individual } \\
\text { materials }\end{array}$} \\
\hline All packaging waste & 65 & 70 \\
\hline Plastics & 50 & 55 \\
\hline Wood & 25 & 30 \\
\hline Non-ferrous metals & 70 & 80 \\
\hline Aluminium & 50 & 75 \\
\hline Glass & 70 & 85 \\
\hline Paper and cardboard & 75 & \\
\hline
\end{tabular}

Source: (own elaboration based on: Directive EU 2018/852)

It is worth noting that the level of recycling of municipal waste in 2018 amounted to the following in for example: Germany 67\%, Slovenia approx. 59\%, Austria almost 58\%, Netherlands approx. 56\%, Lithuania almost 53\%, Italy approx. $50 \%$, Spain $36 \%$, Poland 34\%, Latvia approx. 25\%, Romania 11\%. For the EU as a whole, this indicator was 47\% (Eurostat, 2020). Among other things, the need to meet the above regulations and the currently low level of waste recycling in Poland can be explained by the fact that at the turn of 2019/20 the costs of municipal waste management are soaring. 
In addition to the regulations discussed in more detail above, a number of other regulations related to circular economy have been introduced in the EU, among which Directive EU 2019/904 is one of the most widely commented on. It provides, among others, for a ban on the introduction of a number of plastic products to the market and, in the case of disposable bottles, for $90 \%$ of them (by weight) to be collected, starting from 2029.

From the point of view of circular economy, the EU's climate and energy policy can be considered to be at least integrated and complementary with it, this policy may even be one of the elements implementing this economic model.

The implementation of these objectives will directly contribute to the reduction of the consumption of non-renewable raw materials and the mass of waste associated with their acquisition, as well as the management of residues after their use.

\section{THE IMPACT OF CIRCULAR ECONOMY ON MINING}

The nature of mining results in its good integration into the existing system of linear economy, which is conducive to its development. The common functioning of circular economy will have a multi-faceted impact on mining. On the one hand, changes in the economy will result in mining operating in a new economic environment that significantly reduces its role. On the other hand, the processes being executed in mining companies will have to undergo significant changes to meet the growing requirements resulting from the implementation of circular economy.

The functioning of the economy in the new model is connected with the reduction of demand for raw materials. Almost all regulations introducing circular economy in the EU (including those discussed in the previous chapter) result in reduced demand for extracted non-renewable raw materials:

- the introduction of raw materials obtained from recycling processes into the economic cycle,

- forcing the substitution of products based on non-renewable raw materials with products based on renewable raw materials,

reducing the overall demand for raw materials, e.g. by forcing the possibility of longer use of products (e.g. the package of European Commission Regulations of 1.10.2019. - Commission Regulations EU, 2019 - establishing ecodesign requirements, including the so-called "right to repair"),

- reducing energy demand by, for example, forcing an increase in the energy efficiency of products, the use of recycled raw materials (whose reuse usually involves lower energy consumption in processing), and thus the demand for energy sources.

For example, in 2016, recycling in the EU covered $75 \%$ of demand for lead, $55 \%$ for copper, almost $45 \%$ for vanadium, more than $30 \%$ for zinc, yttrium, nickel, almost $25 \%$ for iron, more than $12 \%$ for aluminium, about $10 \%$ for magnesium, platinum and palladium (Eurostat, 2020). In turn, in 2017, more than $11 \%$ of the EU-wide raw material mass were reused (Eurostat, 2020). At the same time, Favot and Massarutto (2019) pointed to the relatively small share of rare earths 
elements recycled worldwide (less than 1\%). Technical difficulties and the costs of such processes, often exceeding the market prices of these elements, were identified as the cause.

Currently, the concept of "urban mining" is increasingly used in relation to entities recovering particular materials from waste (e.g. "mining"): Akcil, Agcasulu \& Swain, 2019; Arora, 2020).

The adjustment actions of the technological process itself in the scope of the introduction of circular economy in mining plants will have to be of a varied nature, tailored to the specificity of each plant. In the European mining industry, some adaptation measures have even been implemented already (e.g. due to the need to meet the requirements of already existing regulations or the implementation of clean production). However, the changing conditions of the economic environment (enforced by the introduced regulations) will make it more attractive to continue and expand the activities. It is also noteworthy that often the implementation of circular economy will require cooperation with companies belonging to other industries: e.g. building materials and construction, metallurgy, chemical industry, power generation (Zhaoa et al, 2012).

In coal mining, water plays an important role. The amount of water pumped out of the mine drainage is $6-10 \mathrm{~m}^{3} / \mathrm{Mg}$ of hard coal and about $7 \mathrm{~m}^{3} / \mathrm{Mg}$ of lignite coal (Kozioł \& Stechman, 2006; Kasztelewicz, 2018). At the same time, mines use water for technological purposes. Table 2 shows the approximate quantities of water used in the Polish mining industry, in particular devices (own elaboration based on Kozioł \& Stechman, 2006).

Table 2 Water consumption for technological purposes in hard coal mining

\begin{tabular}{|l|c|c|}
\hline \multicolumn{1}{|c|}{ Type of device } & Unit & Water consumption rate \\
\hline Sprinklers & $\mathrm{m}^{3} /$ day spraying point & 7 \\
\hline $\begin{array}{l}\text { Fluid: } \\
\text { coarse charcoal }\end{array}$ & $\mathrm{m}^{3} / \mathrm{Mg}$ of coal & 0.2 \\
coal dust & & 0.8 \\
coking coal & & 0.4 \\
\hline $\begin{array}{l}\text { Compressors: } \\
\text { low pressure } \leq 0.7 \mathrm{MPa} \\
\text { high pressure } \leq 20 \mathrm{MPa}\end{array}$ & $\mathrm{m}^{3} / 10^{3} \mathrm{~m}^{3}$ of air & 0.3 \\
\hline Transportation equipment & & 0.5 \\
\hline $\begin{array}{l}\text { Enrichment of coal in the } \\
\text { following circulations: } \\
\text { open } \\
\text { closed }\end{array}$ & $\mathrm{m}^{3} / \mathrm{Mg}$ of coal & 2 \\
\hline
\end{tabular}

Source: (own elaboration based on: Kozioł \& Stechman, 2006)

After treatment, water from drainage can be used (in exchange for water taken from external suppliers) for plant operations. Water can be used in technological processes (e.g. enrichment and desulphurization of dusts, in mechanical processing of coal) and for economic purposes (it can even feed the municipal water supply system). As shown in Table 2, significant water savings can be achieved by closing water and sewage circuits in mines. Water can also be a source of obtaining salt, which will contribute to reducing one of the major 
problems of mining in many regions of the world - the discharge of saline water into surface natural receivers. Mine drainage water can also be used for energy purposes (e.g. using heat pumps). Drainage water can be treated by means of reverse osmosis methods.

The use of demethane gas for combustion in engines or gas turbines to obtain electricity to drive technological equipment, including mine air conditioning, should be considered an important activity (Szlązak et al., 2001). In this solution, the electricity generated was used to drive the compressor coolers, while the resulting entalphy of exhaust gases and engine cooling water was used in absorption coolers. Another way of partially utilizing waste energy is to use ventilation air as combustion air in steam or water boilers.

The excavations of the deep mines being closed can be used as part of a pumped-storage power stations' layouts or for tourism purposes. An example of such use is a large industrial tourism complex operating in Poland. One of the greatest Polish tourist attractions is the historic salt mine in Wieliczka near Krakow. Two other facilities operate in Silesia: in the city of Zabrze in the facilities of a former coal mine, and in the city of Tarnowskie Góry in the former non-ferrous metal ore mines. For obvious reasons, however, such use of former mines is of very limited significance.

The key issue in the context of circular economy is the use of the solid waste generated. In the EU, more than 642 million Mg of mining and mineral extraction waste was generated in 2016 (Eurostat, 2020), which accounted for more than $25 \%$ of the total waste generated. In Poland, in 2018, over 61 million Mg of mining waste was generated and it accounted for over $48 \%$ of the total mass of generated waste (Statistics Poland, 2019a). A separate problem is the waste already collected in landfills. In Poland alone, there are over 1,760 million Mg of such industrial waste, $46 \%$ of its weight being mining and mineral extraction waste (Statistics Poland, 2019a).

One possibility to use the waste already collected is to reprocess it in order to recover the components still contained in it for the sake of the extraction of which it was originally extracted. Before, such a more accurate recovery was not technically possible. Currently, such recovery may be technically possible and economically rational due to technological development and changing market conditions. Another direction of management of the waste already accumulated and those coming from current production is to find practical applications for it. Such waste is already widely used today: in mining techniques (e.g. for floorings), in construction (e.g. road, hydrotechnical, land levelling, reclamation of degraded areas), in production of building materials (building ceramics, concrete, cements).

Many years of Polish experience in the management of waste from deep coal mining (Kledzik, 2018; Kugiel \& Piekło, 2012) indicate the possibility of costeffective use of mining waste not only in the construction industry, but also to obtain coal dust and components for the production of fuels for the power industry (e.g. production of sludge granulates and mixtures of dust with sludge granulate - Kugiel \& Piekło, 2012). Another product manufactured on the basis 
of coal sludge may be reclamation mixtures (Kugiel \& Piekło, 2012). It is worth mentioning that only the largest Polish company dealing with the management of mining waste has recycled approx. 180 million $\mathrm{Mg}$ of waste over several decades of its operations (Kledzik, 2018). About $40 \%$ of the mass of generated mining waste is used economically in Poland (Statistics Poland, 2019a).

It must also be noted that even though global consumption of bituminous coal has remained at an unchanged level in recent years (according to Statistics Poland (2019b) it amounted to 6.9 billion Mg in 2015, 6.7 billion Mg in 2017, and 7 billion $\mathrm{Mg}$ in 2018), at the same time consumption in the $\mathrm{EU}$ is gradually declining - it amounted to approx. 286 million Mg in 2015, 246 million Mg in 2017, and less than 227 million $\mathrm{Mg}$ in 2018, which is a decrease of more than $20 \%$ over 4 years (Eurostat, 2020). What's more, only approx. 33\% of the coal consumed in the EU was mined within EU, of which $86 \%$ (63.4 million Mg) of bituminous coal was mined in Poland.

The same applies to lignite. The global impact of this type of coal is much smaller, with global production of 803 million Mg in 2018 (Statistics Poland, 2019b), with 46\% (370 million Mg) produced in the EU (Eurostat, 2020).

Therefore, the issue of circular economy applied to coal mining, in particular mining of bituminous coal in the EU and Poland, will increasingly revolve around the issue of managing already accumulated waste.

A Polish planning document for the coming years: The Roadmap for the Transformation Towards Circular Economy (Council of Ministers, 2019) presents courses of action that are similar to the above ones. This document sets out the following direction, among others:

- establishment, in cooperation with the Stock Exchange, of a dedicated trading platform for secondary raw materials;

- establishment and use of landfills for waste from the processing and mining industry, and analysing the properties of the waste collected at these sites for their use in various branches of the Polish industry;

- drafting legislative changes that would enable and promote the use of mining waste.

\section{THE IMPACT OF CIRCULAR ECONOMY ON ENERGY}

As already indicated in the previous chapter, the implementation of the circular economy will involve a decreasing demand for energy. Furthermore, the emphasis on the use of renewable and regional resources will become another element of pressure (alongside climate and energy policies) to increase the use of renewable energy sources, preferably local ones at that.

From the point of view of the processes carried out in municipal and system power plants themselves based on combustion processes, it is important to use water and manage non-flammable by-products of the combustion process, which include among others: ash-slag mixtures from the wet discharge of combustion waste, fly ashes, mixtures of fly ashes and solid waste from calcium flue gas desulphurization methods. 
Waste from the power generation sector, compared to the previously discussed mining waste, is generated in the EU in much smaller quantities - about 78 million $\mathrm{Mg}$ in 2016. (Eurostat, 2020). At the same time, approximately $25 \%$ of this waste is generated in Poland. Apart from Poland, significant amounts of waste from this sector are generated in the following countries of the EU: Germany, Bulgaria, Romania and Estonia. An additional problem is the significant amount of this waste that is landfilled, for example, over 300 million $\mathrm{Mg}$ is landfilled in Poland. The main sources of the waste in question are installations burning hard coal and lignite coal as well as installations for thermal management of municipal waste and sewage sludge.

Waste from the power generation sector is commonly used in: cement production, construction (for the production of concrete, in infrastructure construction, e.g. for land stabilization and for road and bridge construction), land reclamation (levelling and fertilization of land), mining (e.g.: hydraulic and dry foundations, for fire protection, sealing of abandoned workings), road construction (for winter road maintenance). One of the by-products of the flue gas desulphurization process is gypsum, which is used in mass production of building materials.

Some combustion wastes can be a source of valuable raw materials, such as microspheres (Wajda \& Kozioł, 2015). Due to its properties (e.g. low density, thermal insulation, fire resistance), the material is used in a wide range of applications, e.g. in the production of warmth-, heat- and fire-insulating materials, lightweight concretes, as an additive to sealing compounds, a filler for thermoset and thermoplastic materials, as a component of drilling fluids, grinding materials, casting moulds. However, it should be borne in mind that the microsphere occurs in small quantities (1-3\% of the weight) and only in some ashes from pulverized coal-fired furnaces (Wajda \& Kozioł, 2015).

National technologies are in place to make extensive use of the considerable amount of waste in the furnace. As an example, the technology of production of granulates and aggregates from ashes and slags (CBE Poland, 2017) can be given. The materials obtained have a number of applications. They can be: a component of concrete, drainage layers, insulation layers, a component of prefabricated building elements, a substrate for hydroponic cultivation.

In Poland, approximately half the mass of generated waste is used economically (Statistics Poland, 2019a; CBE Poland, 2017).

The power generation sector is one of the largest water consumers. In Poland, in 2018 , this sector accounted for approximately $60 \%$ of total water consumption and almost $70 \%$ of water consumption for industrial purposes (Statistics Poland, 2019b). This water is mainly used for sprinkler cooling. The environmental impact of sprinkler cooling water includes (Zembaty, 2000):

- an increase in the temperature of surface waters (rivers, lakes, reservoirs),

- the loss of water in the cooling tower due to evaporation,

- the discharge of waste water from the decarbonisation and supplementary water filtration installation, 
- microclimate changes in the vicinity of heat-loaded water bodies near the cooling tower.

Recent analyses of the replacement of wet cooling towers by dry cooling towers or direct cooling of sprinklers with fan air.

The Roadmap for Transformation towards circular economy (Council of Ministers, 2019), in addition to the tasks presented in the previous chapter, which concern mining and power generation sector waste, also provides for activities dedicated only to waste from the power generation sector:

- analysing the potential and proposing legislative changes to increase the economic use of by-products of combustion,

- adequate preparation of raw materials (coals), even before their incineration, to enable increased use of the waste resulting from their incineration,

- the development of research into the implementation of innovative solutions to extend the possibility of using the waste in question.

\section{CONCLUSIONS}

Circular economy is a new model of the economy being dynamically implemented in the EU. The implementation of this model is supported by numerous legal acts and an increasingly extensive information campaign. It can be assumed that circular economy measures are in line with the expectations of a large part of the society.

The EU governing bodies as well as the governing bodies of individual member states within the European Community expect the new economic model to deliver significant political and economic benefits in addition to environmental effects. These include: increased independence from external suppliers of raw materials, economic growth and increased employment, especially in the service sector. However, there is concern that without strong pressure from the legal regulations and administration supervising their implementation, the implementation of the new economic model will be slow and will cover only parts of the economy. At the same time, the implementation of the circular economy under the above conditions means an increase in bureaucracy and the possibility for a number of sectors of the EU economy to continue to lose competitiveness if no similar action is taken worldwide.

The main challenges of circular economy for these sectors arise from the need to manage solid waste and to reduce water consumption. The main barriers to greater use of waste (or raw materials obtained from waste) from the economic sectors discussed in the publication should be mentioned:

- higher costs related to the use of recycled raw materials than of newly sourced ones (low economic competitiveness of sourced materials/raw materials or even lack thereof);

- the problems arising from the fact that these wastes often have very different properties depending on the source of origin, which means that the technologies for their preparation and use must be selected individually each time; 
- legal problems resulting, among others from lack of or insufficient preference for the use of the materials/raw materials in question, and ambiguity of the rules in the context of defining a given product as waste or by-product, or the loss of waste status;

- the need to carry out long-term studies (e.g. studies on the variability of properties of manufactured products over time, studies on environmental impact);

- in the case of waste from the power generation sector - decreasing hard coal extraction in Poland (a significant part of it is used in mining),

- uneven demand during the year for the generated waste/raw material, and thus the resulting need to store large amounts of waste from current production.

As presented in the publication, Poland already has a significant track record in the economic use of waste from the mining and power generation sectors. However, for the full implementation of circular economy, it is necessary to further increase the use of existing solutions and to search for new ones (i.e. to conduct R\&D). Legislation is also expected to facilitate the use of waste/raw materials from the mining and power generation sectors in other economic sectors.

It should be noted that for those parts of the mining and power generation sectors already facing a number of problems based on coal mining and combustion, the implementation of circular economy will be another challenge. Facing it will certainly bring significant environmental benefits, but it will not necessarily positively translate into the economic performance of companies.

\section{REFERENCE}

Akcil, A., Agcasulu, I., Swain, B. (2019) 'Valorization of waste LCD and recovery of critical raw material for circular economy: A review', Resources, Conservation and Recycling, 149, pp. 622-637. DOI: 10.1016/j.resconrec.2019.06.031

Arora, M., Raspall, F., Cheah, L., Silva, A. (2020) 'Buildings and the circular economy: Estimating urban mining, recovery and reuse potential of building components', Resources, Conservation and Recycling, 154, 104581. DOI: 10.1016/j.resconrec.2019.104581

Careddu N. (2019) 'Dimension stones in the circular economy world', Resources Policy, 60, pp. 243-245. DOI: 10.1016/j.resourpol.2019.01.012

CBE Poland (2017), Management of combustion by-products - relation [Online], (in Polish). Edroga.pl. Available at: https://edroga.pl/drogi-imosty/zagospodarowanie-ubocznych-produktow-spalania-relacja-190614122 (Accessed: 19 January 2020).

Commission Regulations EU (2019). 2019/2019 to 2019/2024 laying down ecodesign requirements. Official Journal of the European Union L 315, 62, 5 December 2019.

Council of Ministers (2019), Resolution of 10.09.2019. on the Adoption of the Roadmap for the Transition to a Circular Economy, (in Polish). Available at: https://www.gov.pl/web/rozwoj/rada-ministrow-przyjela-projekt-mapy-drogowejgoz (Accessed: 08 January 2020).

Directive EU 2018/850 of the European Parliament and of the Council of 30 May 2018 amending Directive 1999/31/EC on the landfill of waste. Official Journal of the European Union L 150, 61, 14 June 2018. 
Directive EU 2018/851 of the European Parliament and of the Council of 30 May 2018 amending Directive 2008/98/EC on waste. Official Journal of the European Union L 150, 61, 14 June 2018.

Directive EU 2018/852 of the European Parliament and of the Council of 30 May 2018 amending Directive 94/62/EC on packaging and packaging waste. Official Journal of the European Union L 150, 61, 14 June 2018.

Directive EU 2019/904 of the European Parliament and of the Council of 5 June 2019 on the reduction of the impact of certain plastic products on the environment. Official Journal of the European Union L 155, 66, 12 June 2019.

European Commission (2014). Communication From The Commission To The European Parliament, The Council, The European Economic And Social Committee And The Committee Of The Regions Towards a circular economy: A zero waste programme for Europe. Document 52014DC0398. Available at: https://eur-lex.europa.eu/legal-content/EN/TXT/?uri=celex\%3A52014DC0398 (Accessed: 08 January 2020).

European Commission (2015). Communication From The Commission To The European Parliament, The Council, The European Economic And Social Committee And The Committee Of The Regions Closing the loop - An EU action plan for the Circular Economy. Document 52015DC0614. Available at: https://eur-lex.europa.eu/legalcontent/EN/TXT/?qid=1580777401562\&uri=CELEX:52015DC0614 (Accessed: 08 January 2020$)$.

eurostat, (2020).

Database [Online]. Available

at: https://ec.europa.eu/eurostat/data/database (Accessed: 06 February2020).

Favot ,M., Massarutto, A. (2019) 'Rare-earth elements in the circular economy: The case of yttrium', Journal of Environmental Management, 240, pp. 504-510. DOI: 10.1016/j.jenvman.2019.04.002

Kirchherr, J., Reike, D., Hekkert, M. (2019) 'Conceptualizing the circular economy: An analysis of 114 definitions' Resources, Conservation and Recycling, 127, pp. 221232. DOI: 10.1016/j.resconrec.2017.09.005

Kasztelewicz Z. (2018). Report on the condition of the lignite coal industry in Poland and Germany with a diagnosis of activities for the development of this industry in the first half of the 21st century. Cracow: AGH University of Science and Technology. [Online], (in Polish). Available at: https://www.cire.pl/pliki/2/2018/raport_o_stanie_branzy_wegla_brunatnego_w_p olsce_i_w_niemczech.pdf (Accessed: 23 January 2020).

Kledzik, A. (2018) 'Environmental Aspects of the Operations of Haldex S.A. for the Mining Industry and the Silesian Region', Ekologia, 88(4), pp. 46-47.

Kozioł, J. and Stechman, A. (2006). Industrial cooling water. Gliwice: Wydawnictwo Politechniki Śląskiej, (in Polish).

Kugiel, M., Piekło, R. (2012) 'Directions of the Management of extractive waste at Haldex S.A.', Górnictwo i geologia, 7(1), pp. 133-145, [online], (in Polish). Available

at: https://www.polsl.pl/Wydzialy/RG/Wydawnictwa/Documents/kwartal/7_1_12.pdf (Accessed: 15 January 2020).

Makropoulos, C., Rozos, E., Tsoukalas, I., Plevri, A., Karakatsanis, G., Karagiannidis, L., Makri, E., Lioumis, C., Noutsopoulos, C., Mamais, D., Rippis, C., Lytras, E. (2018) 'Sewer-mining: A water reuse option supporting circular economy, public service provision and entrepreneurship', Journal of Environmental Management, 216, pp.285-298. DOI: 10.1016/j.jenvman.2017.07.026

Statistics Poland (2019a). Environment 2019. Spatial and Environmental Surveys Departmen [online]. Available at: https://stat.gov.pl/obszarytematyczne/srodowisko-energia/srodowisko/ochrona-srodowiska-2019,1,20.html (Accessed: 05 February2020).

Statistics Poland (2019b). Statistical Yearbook of the Republic of Poland 2019. Available 
statystyczne/roczniki-statystyczne/rocznik-statystyczny-rzeczypospolitejpolskiej-2019,2,19.html (Accessed: 03 February2020).

Szlązak, J., Szlązak, N., Obracaj D., Borowski, M. (2001). 'Evaluation of the Operation of a Combined Power and Cooling System in the Air Conditioning of an Underground Mine' in Kozioł, J. (ed.) Energy Saving Directions and Methods Industrial Cooling' 2001. Wisła: OBRGE, ITC, PAN, pp.211-224, (in Polish).

Wajda, A., Kozioł, M. (2015) 'Microspheres - obtaining, properties, applications', Piece przemysłowe i kotły, 23(1), pp. 15-19, (in Polish).

Zembaty, W. (2000). 'Environmental Impact of Cooling Systems' in Kozioł, J. (ed.) Energy Saving Directions and Methods - Industrial Water'2000. Wisła: OBRGE, ITC, PAN, pp. 189-206, (in Polish).

Zhaoa, Y., Zanga, L., Lia, Z., Qina J. (2012). 'Discussion on the Model of Mining Circular Economy'. International Conference on Future Energy, Environment, and Materials. Energy Procedia, 16, p. 438-443. DOI: 10.1016/j.egypro.2012.01.071

\begin{abstract}
.
The publication analyses and evaluates the impact of the implementation of circular economy on the economy and especially on its mining and power generation sector in Poland. Circular economy is a relatively new concept concerning an innovative economic development model. The publication briefly describes the concept of circular economy. Among other things, the basic economic processes that make up circular economy are discussed. In addition, history is presented as well as examples of legislation that have had the strongest impact on the implementation of circular economy in the EU are identified. Further on in the paper, the impact that circular economy will have on the mining and power generation industry in Poland is discussed. Areas have been identified that will need the most attention in relation to the implementation of circular economy. It was pointed out that in the mining and power generation sector the scale of use of current and landfill waste should be increased as a priority. Attention has been paid to the necessary reduction of water demand and rational water and sewage management. Examples of use of mining gas and ventilation air have been discussed. The publication provides examples of a number of measures taken in accordance with circular economy. It was pointed out that there is still a need to popularize the existing ones and to look for new technical and organizational solutions conducive to the introduction of this new economic model. An important aspect of the impact of the circular economy on these sectors will be the decrease in energy demand resulting from the widespread implementation of the new economic model. For those already struggling with a number of problems of some of the mining and power generation sectors based on coal mining and combustion in Poland, the implementation of circular economy will pose another challenge.
\end{abstract}

Keywords: circular economy, combustion by-products, industrial waste management, mining waste 